\title{
The Janus faced teacher educator
}

\author{
Kari Smith ${ }^{a}$ and Maria Assunção Flores ${ }^{b}$

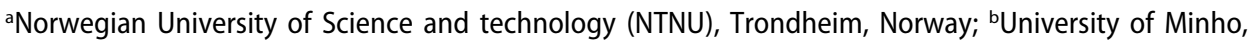 \\ Braga, Portugal
}

\begin{abstract}
This paper focuses on the Janus face-teacher educator and researcher. Drawing on existing international literature, our aim is to position ourselves in the discussion relating to our own and other research. In this paper we limit ourselves to discuss two main components, namely teaching and research in relation to which teacher educators seem to experience a rather strong tension. We maintain that the quality of teaching does not become inferior to research and publishing in teacher education. This necessitates that sufficient resources are provided for assuring the quality of teaching and for research; subsequently the two activities are complementary and not contradictory to each other. Our claim is that teacher educators in most settings are Janus-faced due to the competing demands of excellence in both research and teaching. However, we strongly believe that the two main responsibilities of teacher educators which form the Janus face, can melt into each other in the face of a researching teacher educator.
\end{abstract}

\section{ARTICLE HISTORY}

Received 26 April 2019

Accepted 17 July 2019

\section{KEYWORDS}

Teacher educators; research; teaching; teacher education

\section{Introduction}

Quality teaching is key to improve student learning. Quality teaching depends on teacher quality which is seen as one of the most important school-related factors influencing student achievement (OECD 2005; Darling-Hammond 2000; Hattie 2003). Teacher quality depends on quality teacher education. Thus, teacher educators play a key role in the process of teacher learning (EU 2013). There has been extensive research on teaching and teachers, but less attention has been paid to teacher educators.

More recently, it is possible to identify research which has focused on teacher educators, in particular on their roles and responsibilities and on their professional learning (Kelchtermans, Smith, and Vanderlinde 2018; Meeus, Cools, and Placklé 2018; Bouckaert and Kools 2018; Yamin-Ali 2018; Shagrir 2019). While there has been growing attention to teacher educators, existing literature points to divergent orientations and, to some extent, to lack of clarity in regard to who they are, what they do, and how they develop professionally (Flores 2018; Ping, Schellings, and Beijaard 2018). As Murray (2016) argues, teacher educators are 'an under-researched, poorly understood, and illdefined occupational group'.

Added to this is the complex and varied nature of their roles, particularly regarding research, teaching and teaching how to teach. In this context, tensions related to how teacher

CONTACT Kari Smith kari.smith@ntnu.no Norwegian University of Science and technology (NTNU), Norway 
educators handle the two man roles - teaching and research - have been identified (Murray and Male 2005; Czerniawski, MacPhail, and Guberman 2017). Teacher educators have been viewed as 'hidden' or 'unrecognised' professionals (Livingston 2014) within a multi-faceted (EU 2013) and heterogeneous profession (Smith 2011; Ping, Schellings, and Beijaard 2018). Issues of invisibility, diversity, complexity, and sometimes ambiguity have been used to describe the characteristics of teacher educators' work. Within this complexity of roles, teacher educators develop professional identities related to practicing agency, 'their capacity to negotiate and renegotiate professional identities within their local work practices' (Hökkä, Eteläpelto, and Rasku-Puttonen 2012, 86) in the attempt to handle the many different responsibilities. Initiatives led by teacher educators in different parts of the world in order to foster their professional development may be identified (Shagrir 2019) namely through communities of practice (Shagrir 2019; Hadar and Brody 2018), self-studies and study groups (see, for instance, Flores et al. 2016; Vieira et al. 2019). Issues such as building collective responsibility for improving teacher education programmes, providing support, developing a shared commitment to student teacher learning and developing a scholarship of teacher education have been discussed as a result of such initiatives. However, in other contexts, dilemmas, tensions and concerns associated with the complexity of teacher educators' role and practice have also been identified (see, for instance, Vieira 2013; Meeus, Cools, and Placklé 2018; Maareneen et al. 2019). It is, therefore, important to examine who teacher educators are and what they do, how they understand their roles and their professional learning and development (see, for instance, Izadinia 2014; Livingston 2014; Flores 2016; Czerniawski, MacPhail, and Guberman 2017; Hadar and Brody 2018; Springbett 2018). This paper focuses in particular on the Janus face- teacher educator and researcher. It draws on existing international literature, and our aim is to position ourselves in the discussion relating to our own and other research.

\section{Who is the teacher educator and how are his/her roles described?}

As a backdrop to discussing who is the teacher educator and what his/her roles are, it is useful to problematise the university context in which teacher educators work. Labaree (2004) talks about the low status of Ed-school in American tertiary institutions, and at the same time criticised them for being distant to the practice field. Brennan and Willis (2008), describing the Australian context, claim that: Education is not a top discipline in the university sector (s. 297). Teacher education has, in many countries, previously mainly taken place in colleges, and not in universities, yet since the 1990 there has been a process of merging teacher education colleges with universities in for example UK, Australia, New Zealand, and recently also in Norway. Thus, teacher education must find its place within the university structure and develop an academic identity which fits into a university model. Teacher educators who in the past identified themselves mainly as 'teachers', are now required to develop new identities to fit the university model. A look at existing research literature points to the vagueness of the definition of the term 'teacher educator'. This lack of clarity leads, in turn, to the vague definition of who teacher educators are with implications for their identities, role description and professional development. In a recent paper, White (2019) asserts that defining who the teacher educator is depends on 'which country and work context you are located in; it depends on which position and perspective you take on the wider project of educating 
teachers, and it depends on individuals who either choose to identify or not, as a member of this group'.

Attempts have been made to overcome the lack of a shared and clear understanding of the term in existing literature. For instance, teacher educators have been described as 'all those who actively facilitate the (formal) learning of student teachers and teachers' (EU $2013,8)$. In a similar vein, Snoek, Swennen, and van der Klink M $(2011,652)$ state that a teacher educator is 'someone who contributes in a formal way to the learning and development of teachers'. These definitions entail a broad understanding of the concept which includes those who work in universities (including those who teach school subjects) as well as school based mentors. The above definitions particularly highlight the formal dimension in which teacher educators' work is embedded. As White (2019) asserts recently, teacher educators 'remain poorly understood and yet paradoxically vital to policy reform'.

Multiple or sub-identities as teacher educators may be identified as they may see themselves in different ways. For instance, school mentors might, rightly so, think of themselves primarily as school teachers, and teachers in higher education are likely to see their roles mainly as researchers and/or as teachers of teachers (Swennen, Jones, and Volman 2010). In order to answer the question 'who is the teacher educator?' it is important to consider the components of the teacher education curriculum (Flores 2016) and to include into the equation those who are involved in teaching disciplinary knowledge, didactical knowledge, general pedagogy, and teaching practice, i.e. foundational courses, content knowledge courses, and teaching practice courses. As such a wide definition of teacher educators is advocated including all involved with the education of teachers regardless of the context and content. In other words, there are multiple teacher educators who are to be associated with various primary expertise and role in the education of (student) teachers in different contexts of learning. White (2019), in a recent literature review and local policy analysis study in the Australian context, identifies three sub-groups belonging to the broader teacher educator occupational group: i) university-based; ii) school-based; and iii) community-based teacher educators (for instance, parents, community leaders and, in examples from both Canada and Australia, Indigenous Elders). Each of these categories plays a key role in the education of teachers across their career to best meet the needs of all students.

Other issues pertaining to the complex and demanding nature of teacher educators' professional knowledge and work have also been discussed in recent research literature. Smith (2015) claims that teacher educators is a professional group within another professional group, that of teachers. There is a certain unique combination of characteristics of teacher educators' professional knowledge and skills, such as content knowledge, communicative knowledge, knowledge about adult learning, feedback and motivation, research knowledge, and how to develop reflective competence within others (Smith and Ulvik 2015). Taking into consideration that a specialised professional education for teacher educators is rare or non-existing in most contexts, teacher educators' professional knowledge is mainly acquired through experience. In Israel Orit Avidov-Ungar and Forkosh-Baruch (2018) studied the professional identity of teacher educators with regards to pedagogical innovation, including being, the conceptual component; doing, the practical component; and having, the environmental support component. The authors found that the 'being' component is the dominant mode of existence and is strongly connected to the construction of professional selves. They also 
conclude that the demands of the digital era compel teacher educators to re-examine their professional identity vis-a-vis technology-integrated teaching and that institutional support was vital for professional identity construction.

Other studies have examined how teacher educators enacted their roles differently within a school-based development project (Postholm 2019) and their collective professional agency and identity within an identity coaching programme (Hökkä, Vahasantanen, and Mahlakaarto 2017). Recent research has also focused on their professional roles (Meeus, Cools, and Placklé 2018; Bouckaert and Kools 2018; Yamin-Ali 2018), on their professional learning, development and change (Brody and Hadar 2018; Czerniawski et al. 2018), on their conceptualisation of the teaching/learning process (Kosnik et al. 2018; Cao et al. 2018), and on their identities and the integration of technology (Jonker, Marz, and Voogt 2018; Uerz, Volman, and Kral 2018). This literature emphasises the tensions teacher educators encounter in their work, in some cases related to a mismatch between their own expectations and the expectations of their institutions as well as the need to better align their professional development with their needs and career stages including both formal and informal learning contexts. An expansion of their roles, lack of support, scarcity of relevant professional development opportunities, tensions between research and teaching and lack of visibility of their work have also been identified. In a recent systematic review of what, how and why teacher educators learn, Ping, Schellings, and Beijaard (2018), drawing on 75 research articles, concluded that while research on teacher educators' professional learning appears to be a growing field of interest, it is fragmented in focus. The same authors found that i) there is no clear knowledge base essential for teacher educators' work, ii) teacher educators undertake different activities from which to learn, and iii) they generally experience the need to learn to do their work as teacher educators.

The importance of reflecting on teacher educators' practice and research as a strategy of professional development has also been explored within the framework of the selfstudy movement (see, for instance, Russell and Martin 2014; Russell 2018). A Finnish study suggests, however, that teacher educators express more confidence in exerting agency in their teaching roles than in their roles as researchers (Hökkä, Eteläpelto, and Rasku-Puttonen 2012). Moreover, research has shown that teacher educators are a particular group of teachers as their instructional practices are significantly different from those of other higher education faculty in terms of the use of various types of traditional and constructivist strategies (Goubeaud and Yan 2004). Cao et al. $(2018,481)$ argue that 'The uniqueness of teaching in teacher education is that the focus of teaching is not just on what student teachers should know and believe about teaching, but more importantly on what student teachers actually do when they are teaching'.

In this paper we discuss school-based and university based teacher educators (e.g. the mentors or cooperating teachers in the schools during practicum and beyond) in order to shed additional into their identity and work and particularly into the ways in which they deal with varied and sometimes competing demands embedded in their professional responsibilities.

\section{Teaching and research}

Drawing upon data about the process of enacting change in initial teacher education, as a result of the Bologna process, Vieira et al. $(2019,53)$ identified resistance, tensions, and 
dilemmas as 'tradition and innovation are difficult to reconcile within organisational cultures that tend to be conservative, and where divergent interests and power imbalances often undermine democratic debate and the resolution of problems'. The authors argue for a scholarship of teacher education in order to recognise teacher educators' agency and to empower them to deal with the challenges of local reforms. The question is what does this scholarship entail? In the current paper we limit ourselves to discuss two main components, namely teaching and research. Teacher educators seem to experience a rather strong tension between the two activities identified (Murray and Male 2005; Czerniawski, MacPhail, and Guberman 2017). Whereas university based teacher educators' careers are directly affected by the increasing demand to conduct research and publish, school-based teacher educators experience the research pressure to a lesser degree. However, when more and more teacher education programmes are at a higher degree level, school-based teacher educators are expected to support student teachers in their practice oriented research assignments, and also to continuously examine their own teaching practice (Aspfors and Fransson 2015). In other words, school based teacher educators are expected to be research literate.

Consequently, there is an increasing pressure on all teacher educators not only to be 'smart consumers of research' (Loughran 2014) meaning that they understand research (Cochran-Smith 2005), but also to be producers of research, for example by systematic studying their own practice in the search for constant improvement (Berry 2007; Loughran 2010, 2014). Zeichner, acknowledging the importance of practitioners' selfstudy research, however, also warns about the danger of staying too personal and local, not addressing issues discussed in the wider context of teacher education research:

"Although acknowledging the positive professional development impact of self-study on teacher educators, this article calls for more closely connecting the self-studies of teacher educators to the mainstream of teacher education research so that the voices of practicing teacher educators are incorporated into syntheses of research on particular aspects of teacher education», (Zeichner 2007, 36).

Teacher educators are expected to be involved with research, but they do not all feel they are competent to conduct research. Czerniawski, MacPhail, and Guberman (2017), reporting on a survey $(n=1158)$ from 6 countries conducted by the International Forum for Teacher Educator Development (InFo-TED), conclude that the most commonly expressed development needs teacher educators have, are to acquire research skills and academic writing skills. They want to build up a research portfolio for career movement as well as acquiring more knowledge about how to find the appropriate journals for eventual publications. An academic teacher education is located at institutions of higher education, and subsequently people involved with teacher education are expected to be active researchers and to publish in peer-reviewed journals. The challenge is, however, that many of them are not sufficiently research literate and experience a lack of support in learning about research (Czerniawski, MacPhail, and Guberman 2017).

The expectation for all teacher educators to be research competent is closely related to the increasing quest for a research based (informed) teacher education. Students of teaching in many countries, e.g. Finland and Norway, and to a great extent in Portugal, are expected to develop research competence during initial teacher education and to be actively involved with research (Smith 2017). This, however, requires that teacher educators 
at the university and in school are not only smart consumers of research, but research literate so they are able to both model practice-oriented research in addition to teaching research methods and be involved in the supervision of students' research assignments. Many teacher educators come into teacher education from school teaching (Murray and Male 2005; Loughran 2014), and do not hold the required research competence. As Czerniawski, MacPhail, and Guberman (2017) state, this seems to be a shared concern across contexts and national borders.

An additional issue less addressed is if conducting research makes a better teacher educator and improves the quality of teaching in teacher education. When looking at the self-study literature (Zeichner 2007; Loughran 2014; Vanassche and Kelchtermans 2016), it suggests this is the case, mainly regarding how teacher educators perceive their own practice. By the help of research they become aware that they do not always address or achieve the goals they have set when planning their teaching. Vanassche and Kelchtermans (2016) support previous research (Berry 2007, among others) and argue that teacher educators experience tension between teaching and research, and between aligning their personal beliefs and values with institutional and national norms and frameworks. Ulvik and Smith (2019) found that teacher educators and students of teaching in Norway value teacher educators' research activities differently. Teacher educators acknowledge the need for being involved with research, however, they also fear that spending more time on conducting research and writing for publication will leave them with less time to prepare and practice quality teaching. Student teachers, on the other hand, are less appreciative of their teacher educators' research activities, and are more interested in relevant and recent teaching experience teacher educators can share with them. Consequently, there is a tension also between the central participants', teacher educators' and students' views on research. Vanassche and Kelchtermans (2016) maintain that there is a need to find a balance between research and teaching in teacher education. We would argue that it is a matter of how teacher educators' role and scholarship are defined. We maintain that the quality of teaching does not become inferior to research and publishing in teacher education. This necessitates that sufficient resources are provided for assuring the quality of teaching and for research, subsequently the two activities are complementary and not contradictory to each other.

Similarly, there are teacher educators without any teaching experience from school, but who come into teacher education with a disciplinary $\mathrm{PhD}$ and hold a strong research competence. They have a different form for first-order expertise (Murray and Male 2005) research, and these teacher educators need to acquire a second- order expertise of teaching and become acquainted with the school system. Both types of teacher educators are in need of professional development activities in order to strengthen their second-order expertise to satisfactory be able to provide a good education for students of teaching (Smith 2011). Consequently, we argue that there is not a uniform model for teacher educators' professional development, there is no one size that fits all. Teacher educators' expertise differs, which requires providing opportunities for bespoke professional development activities (OECD 2018)

Communities of practice, groups of people who share a common goal and meet regularly to share experiences, learn from each other, and jointly search for ways to improve practice (Wenger, McDermott, and Snyder 2002) is often discussed in relation to 
teachers' professional development, but less so concerning teacher educators' learning. Pyrko, Dörfler, and Eden (2017) reason that for a community of practice to thrive, thinking together is essential.

“... people engaged in thinking together guide one another through their understanding of the same problem. However, this understanding relates not only to technical, practical or theoretical knowledge (the main focus in indwelling), but also to the understanding of the (historical) relationships and communities that are relevant to the given practice" (p. 394).

Leaning on Pyrko, Dörfler, and Eden (2017) paper, our claim is that various types of teacher educators engaging in communities of practice come with diverse professional backgrounds, histories and expertise, and are likely to belong to multiple communities of practice. However, our claim is that the professional development of teacher educators will benefit from teacher educators' communities of practice at an institutional, national and international level. There is a need for starting thinking together, making tacit knowledge explicit and accessible to other members of the community. With this as a starting point, research strong, as well as teaching strong, teacher educators create opportunities to enrich each other and to make the teacher educator profession stronger.

\section{European, national and local initiatives}

The need to invest in teacher educators' professional growth has been advocated through an agenda for research, policy and practice focusing on teacher educators' professional development at a European and national and local initiatives. Below we present a few examples of communities of practice at the various levels.

\section{InFO-TED}

An example of a European initiative aimed at fostering the professional development of teacher educators is InFo-TED in which the first author is the leading coordinator. InFoTED (https://info-ted.eu/) is an international forum of teacher educators from seven countries working to develop and implement knowledge bases of teacher educators; to make the knowledge bases accessible on line, to develop and implement supportive guidelines for induction and professional learning programmes, and to explore how an enduring international supportive structure can be implemented for professional development activities. The core of InFo-Ted's work is the conceptual model for teacher educator development (see Kelchtermans, Smith, and Vanderlinde 2018, 126). The model illustrates the stance taken by InFo-TED, that

\footnotetext{
"The starting point for the professional development of teacher educators, in our opinion, needs to be their practice. We start from the assumption that acting teacher educators have good reasons for doing their job the way they are doing it. That starting point then gives a positive appreciation of the practice in which teacher educators 'enact' their expertise. This is radically different from a deficit approach in which teacher educators' practices would be evaluated against the normative outline of the necessary competencies or evidence-based 'best practices'» (Kelchtermans, Smith, and Vanderlinde 2018, 125).
}

Info-TED thus claims that explicit lists of standards should not be the starting point or the goals for teacher educators' professional development, but that the individual teacher educator, or communities of teacher educators, start by examining their own practice 
which will then guide the professional development activities. This stance is supported by Tack et al. (2018), drawing upon a large-scale survey with 611 teacher educators and on five focus group with 24 participants in Flanders, identify a 'structural need' for teacher educators' participation in professional development activities that are closely linked to their own practices and organised within the context of long-term perspective.

At national levels there are several initiatives in European countries, and some of them are briefly described in the following.

\section{NAFOL in norway}

In Norway a National Research School in Teacher Education (NAFOL) was established in 2010 to promote research by teacher educators, with the aim to strengthen institutional research activities in teacher education, to develop a research-based knowledge base for teacher education, and to prepare teacher educators for supervising student teachers research' projects. The vast majority of Norwegian teacher education institutions are members of the national network which offers additional support beyond the institutional doctoral programs, to teacher educators undertaking the demanding task of getting a PhD. Ongoing external and internal evaluations of NAFOL document that graduates from the research school impact the research interests and activities in the network institutions, and that the NAFOL graduates develop a researching teacher educator identity (Vattoy and Smith 2018). Recently school based teacher educators, supported by the school or by a local municipality have increasingly joint NAFOL, engage practice oriented research with relevance to their own and other schools.

\section{MOFET in Israel}

In Israel the MOFET Institute was established in 1984 by the Department of Teacher Education of the Israeli Ministry of Education as a 'body to initiate and provide frameworks and platforms suitable for the professional development of teacher educators' (Shagrir 2019, 227) Three types of activity frameworks are developed at MOFET: frameworks for learning leading to professionalism and expertise, frameworks for developing the body of knowledge about the teacher education profession and frameworks for professional communities of practice (Shagrir 2019). MOFET includes a wide array of activities such as discussions, workshops, meetings with known experts, study trips and using online learning technologies. Added to these are activities directed to enable the initiation, leadership and development of scientific research as well as activities to foster academic writing and publications. Also included is the establishment of professional communities of practice in which participants hold discussions and debates, constructed outputs such as position papers, documents defining roles, etc. These communities may take the form of think tanks, focus groups and position-holders' forums (Shagrir 2019).

\section{The flemish initiative}

Since 2018, the Flemish Government (Belgium) is subsidizing an educational program for teacher educators. This educational program replaces the local and ad hoc initiatives into a Flemish broad initiative that is coherent and integrated. The educational program consists of 20 ECTS credits and is open for teacher educators with a minimum of 3 years' experience. The program has a unique focus on teacher educators' role as 'teachers of teachers'. The curriculum consists of 5 subjects 1/Teacher educators' professionalism, 2/Practitioner 
research, 3/Curriculum development, 4/Collaboration and organization, and 5/Guidance of reflective experience learning. Within the subjects, teacher educators' own practices are brought together with theory and recent research results (personal communication with Ruben Vanderlinde, 09.04.19).

\section{The VELON in the Netherlands}

In the Netherlands the Dutch Association for Teacher Educators, VELON, with 1500 members, developed a professional standard, a registration procedure, and a knowledge base for teacher educators. According to VELON, 'The knowledge base is intended as support, source of inspiration, instrument and/or tool with which you can direct your professionalization or development in your own way'. The second, revised version of the knowledge base (developed 2016-2019) consists of seven areas:

(1) The teacher educator

(2) The context of teacher education

(3) Subject content and subject pedagogy

(4) Teacher education: cooperation between school and teacher education institution

(5) Research in teacher education

(6) Teacher Education: policy and organisation

(7) Norms and values in teacher education

There is also a specific program for teacher educators available. The programme supports teacher educator in their professional development and in the preparation for the registration. Registration is voluntary (personal communication with Mieke Lunenberg, 08.07.2019).

\section{The NEIP in Portugal}

In Portugal, there is not yet a national initiative to promote teacher educators professional development, yet local pockets of interest/excellence such as NEIP, Portuguese acronym for Núcleo de Estudos e Inovação da Pedagogia (Group of study and innovation of pedagogy) in which the second author has been involved (Vieira et al. 2016). One of the overarching aims was to develop a research culture on and in initial teacher education and a scholarship of teacher education aiming to better understand and to improve teacher educators' practices through questioning the rationales and the implications of their work (Flores, Vieira, and Ferreira 2014). The NEIP was the result of a Working Group in place between 2010 and 2013 aimed at fostering pedagogical innovation at the Institute of Education at the University of Minho (GT-IP). The NEIP was formally created in late 2013 and it started its work in January 2014. Amongst its activities were studies about pedagogical issues; support to experiences of innovation of practice; pedagogical talks; seminars about pedagogical innovation; publications; pedagogical resources and materials and scientific events. One of its main achievements was the creation of a local community of teacher educators who initiated a circle of studies on the post-Bologna master degrees in teaching. Unfortunately, the NEIP, along with other local working groups, was eventually extinguished in 2016 by the Dean of the Institute of Education, and therefore lost institutional support and became an informal initiative. 


\section{Conclusions}

The focus of this paper has been teacher educators' professional development aimed to enhance the scholarship of teacher educators. The role of teacher educator is complex (Loughran 2014), and there is more to scholarship of teacher educators than discussed in the current paper. Our claim is that teacher educators in most settings are Janus-faced due to the competing demands of excellence in both research and teaching. Teacher educators are in this paper defined as faculty members of higher education institutions or involved with initial and induction teacher education as school-based teacher educators, many of whom work within a context of what policy makers call a research-based teacher education. Subsequently, they are expected to be smart consumers and active producers of research. The other side of the Janus face is that all teach about teaching and are therefore expected to model high-quality teaching and all that this entails.

Our position is that the competing demands on teacher educators are not sufficiently rooted in the understanding of who teacher educators are, their background and expertise. They form a diverse group, and as such their needs for professional development activities differ. We argue that teacher educators as a profession has not been sufficiently addressed by policy makers. In 2013, The European Commission issued a document called Supporting Teacher Educators for better learning outcomes (http://ec.europa.eu/assets/eac/education/ policy/school/doc/support-teacher-educators_en.pdf) in which they claim that:

\footnotetext{
"Teacher educators are crucial players for maintaining - and improving - the high quality of the teaching workforce. They can have a significant impact upon the quality of teaching and learning in our schools. Yet they are often neglected in policy-making, meaning that some Member States do not always benefit fully from the knowledge and experience of this key profession. It also means that teacher educators do not always get the support and challenge they need, for example in terms of their education and professional development" (p.4).
}

Whereas the attention to teacher educators' work and development has drawn increased attention among the research community as briefly presented in the introduction of this paper, we argue that European policy makers have not addressed the criticism and the plea made by the European Commission in 2013. The few initiatives are sporadic, some of which are mentioned above. At the European level the profession itself, experienced teacher educators, started InFo-Ted, and the Dutch VELON is another initiative that started from the grassroot. Governmental support has been given to some of the other examples as in Belgium, Norway and Israel, in most cases after active engagement of teacher educators.

The most urgent challenge the authors of this paper currently observe is the increased pressure on research and publication without sufficient resources for the institutions and for the practicing teacher educators. Our concern is that the publication pressure will be at the expense of the quality of teaching in teacher education. Excellent teacher educators whose expertise is teaching might leave the profession, others will not have time to prepare good teaching. Finally, when engaging in research and publication without sufficient competence, the quality of teacher education research is also in danger of being impoverished. There is a need to find a good balance (Vanassche and Kelchtermans 2016) at the individual, institutional and national level, in which research and teaching in teacher education is intertwined. We strongly believe that the two main responsibilities of teacher educators which form the Janus face can melt into each other in the face of a researching teacher educator, yet we are still not there. 


\section{Disclosure statement}

No potential conflict of interest was reported by the authors.

\section{Notes on contributors}

Kari Smith is a Professor (Ph.D.) of education at the Department of Teacher Education, Norwegian University of Science and Technology (NTNU). Her main research interests are mainly teacher education, professional development, mentoring novice teachers and assessment for and of learning. She has acted as the Head of Teacher Education programs abroad as well as at the University of Bergen, Norway. Currently she is the Head of the Norwegian National Research School in Teacher Education (NAFOL). She was the project leader of the International Forum for Teacher Educator Development (InFo-TED) from 2013-2019.

Maria Assunção Flores is a Professor (Ph.D.) of education at the University of Minho, Portugal. She has published extensively in international and national journals, books and book chapters. Her research interests include teacher education and professional development, teacher evaluation, curriculum, assessment, teacher identity and higher education. She was the Chair of the International Study Association on Teachers and Teaching (ISATT) between 2013 and 2019. She is currently President of the Board of Estreiadiálogos (The International Collaborative Action Research Network for the Portuguese speaking countries).

\section{References}

Aspfors, J., and G. Fransson. 2015. "Research on Mentor Education for Mentors of Newly Qualified Teachers: A Qualitative Meta-synthesis." Teaching and Teacher Education 48: 75-86. doi:10.1016/ j.tate.2015.02.004.

Avidov-Ungar, O., and A. Forkosh-Baruch. 2018. "Professional Identity of Teacher Educators in the Digital Era in Light of Demands of Pedagogical Innovation." Teaching and Teacher Education 73: 183-191. doi:10.1016/j.tate.2018.03.017.

Berry, A. 2007. "Reconceptualizing Teacher Educator Knowledge as Tensions: Exploring the Tension between Valuing and Reconstructing Experience." Studying Teacher Education 3 (2): 117-134. doi:10.1080/17425960701656510.

Bouckaert, M., and Q. Kools. 2018. "Teacher Educators as Curriculum Developers: Exploration of a Professional Role." European Journal of Teacher Education 41 (1): 32-49. doi:10.1080/ 02619768.2017.1393517.

Brennan, M., and S. Willis. 2008. "Sites of Contestation over Teacher Education in Australia." Teachers and Teaching: Theory and Practice 14 (4): 295-306. Special Issue: Politics and policy in teacher education: International perspectives. doi:10.1080/13540600802037702.

Brody, D. L., and L. Hadar. 2018. "Critical Moments in the Process of Educational Change: Understanding the Dynamics of Change among Teacher Educators." European Journal of Teacher Education 41 (1): 50-65. doi:10.1080/02619768.2017.1372741.

Cao, Y., L. Postareff, S. Lindblom, and A. Toom. 2018. "Teacher Educators' Approaches to Teaching and the Nexus with Self-efficacy and Burnout: Examples from Two Teachers' Universities in China." Journal of Education for Teaching 44 (4): 479-495. doi:10.1080/02607476.2018.1450954.

Cochran-Smith, M. 2005. "Teacher Educators as Researchers: Multiple Perspectives." Teaching and Teacher Education 21: 219-225. doi:10.1016/j.tate.2004.12.003.

Czerniawski, G., D. Gray, A. MacPhail, I. Bain, P. Conway, and A. Guberman. 2018. “The Professional Learning Needs and Priorities of Higher-education Based Teacher Educators in England, Ireland and Scotland." Journal of Education for Teaching 44 (2): 133-148. doi:10.1080/02607476.2017.1422590.

Czerniawski, G., A. MacPhail, and A. Guberman. 2017. "The Professional Development Needs of Higher Education-based Teacher Educators: An International Comparative Needs Analysis." European Journal of Teacher Education 40 (1): 127-140. doi:10.1080/02619768.2016.1246528. 
Darling-Hammond, L. 2000. “Teacher Quality and Student Achievement: A Review of State Policy Evidence." Educational Policy Analysis Archives 8 (1): 1-44. doi:10.14507/epaa.v8n1.2000.

EU. 2013. "Supporting Teacher Educators for Better Learning Outcomes." European Commission. http://ec.europa.eu/assets/eac/education/policy/school/doc/support-teacher-educators_en.pdf

Flores, M. A. 2016. "Teacher Education Curriculum." In International Handbook of Teacher Education, edited by J. Loughran and M. L. Hamilton, 187-230. Dordrecht: Springer Press.

Flores, M. A. 2018. "Editorial. "tensions and Possibilities in Teacher Educators' Roles and Professional Development."." European Journal of Teacher Education 41 (1): 1-3. doi:10.1080/ 02619768.2018.1402984.

Flores, M. A., F. Vieira, and F. I. Ferreira. 2014. “Formação Inicial De Professores Em Portugal: Problemas, Desafios E O Lugar Da Prática Nos Mestrados Em Ensino pós-Bolonha." In A Formação Inicial De Professores Em Diferentes Contextos. Políticas, Práticas E Perspectivas, edited by M. C. Borges and O. F. Aquino, 61-96. Uberlândia: EDUFU.

Flores, M. A., F. Vieira, J. L. Silva, and J. Almeida. 2016. "Integrating Research into the Practicum: Inquiring into Inquiry-based Professional Development in post-Bologna Initial Teacher Education in Portugal." In Redefining Teacher Education for the Post-2015 Era: Global Challenges and Best Practice, edited by M. A. Flores and T. Al-Barwani, 109-124. New York: Nova Science Publisher.

Goubeaud, K., and W. Yan. 2004. "Teacher Educators' Teaching Methods, Assessments, and Grading: A Comparison of Higher Education Faculty's Instructional Practices." The Teacher Educator 40 (1): 1-16. doi:10.1080/08878730409555348.

Hadar, L. L., and D. L. Brody. 2018. "Individual Growth and Institutional Advancement: The In-house Model for Teacher Educators' Professional Learning." Teaching and Teacher Education 75: 105-115. doi:10.1016/j.tate.2018.06.007.

Hattie, J. 2003. "Teachers Make a Difference: What Is the Research Evidence?" Paper presented at Australian Council for Educational Research Conference, Melbourne, October. Accessed 13 March 2018. http://research.acer.edu.au/research_conference_2003/4

Hökkä, P., A. Eteläpelto, and H. Rasku-Puttonen. 2012. "The Professional Agency of Teacher Educators amid Academic Discourses." Journal of Education for Teaching 38 (1): 83-102. doi:10.1080/02607476.2012.643659.

Hökkä, P., K. Vahasantanen, and S. Mahlakaarto. 2017. "Teacher Educators' Collective Professional Agency and Identity - Transforming Marginality to Strength." Teaching and Teacher Education 63: 36-46. doi:10.1016/j.tate.2016.12.001.

Izadinia, M. 2014. "Teacher Educators' Identity: A Review of Literature." European Journal of Teacher Education 37 (4): 426-441. doi:10.1080/02619768.2014.947025.

Jonker, H., V. Marz, and J. Voogt. 2018. "Teacher Educators' Professional Identity under Construction: The Transition from Teaching Face-To-face to a Blended Curriculum." Teaching and Teacher Education 71: 120-133. doi:10.1016/j.tate.2017.12.016.

Kelchtermans, G., K. Smith, and R. Vanderlinde. 2018. "Towards an 'international Forum for Teacher Educator Development': An Agenda for Research and Action." European Journal of Teacher Education 41 (1): 120-134. doi:10.1080/02619768.2017.1372743.

Kosnik, C., L. Menna, P. Dharamshi, and C. Beck. 2018. "Constructivism as a Framework for Literacy Teacher Education Courses: The Cases of Six Literacy Teacher Educators." European Journal of Teacher Education 41 (1): 105-119. doi:10.1080/02619768.2017.1372742.

Labaree, D. 2004. The Trouble with Ed Schools. New Haven, CT: Yale University Press.

Livingston, K. 2014. "Teacher Educators: Hidden Professionals?" European Journal of Education 49 (2): 218-232. doi:10.1111/ejed.2014.49.issue-2.

Loughran, J. 2010. "Seeing Knowledge for Teaching Teaching: Moving beyond Stories." Studying Teacher Education 6 (3): 221-226. doi:10.1080/17425964.2010.518490.

Loughran, J. 2014. "Professionally Developing as a Teacher Educator." Journal of Teacher Education 65 (4): 271-283. doi:10.1177/0022487114533386.

Maareneen, L., H. Kynäslahti, R. Byman, R. Jyrhämä, and S. Sintonen. 2019. "Teacher Education Matters: Finnish Teacher Educators' Concerns Beliefs, and Values, European." Journal of Teacher Education 42 (2): 211-227. 
Meeus, W., W. Cools, and I. Placklé. 2018. “Teacher Educators Developing Professional Roles: Frictions between Current and Optimal Practices." European Journal of Teacher Education 41 (1): 15-31. doi:10.1080/02619768.2017.1393515.

Murray, J. 2016. "Beginning Teacher Educators: Working in Higher Education and Schools." In International Handbook of Teacher Education, edited by J. Loughran and M. Hamilton, 35-70. Singapore: Springer.

Murray, J., and T. Male. 2005. "Becoming a Teacher Educator: Evidence from the Field." Teaching and Teacher Education 21: 125-142. doi:10.1016/j.tate.2004.12.006.

OECD. 2005. Teachers Matter: Attracting, Developing and Retaining Effective Teachers. Paris: OECD Publishing.

OECD. 2018. Effective Teacher Policies: Insights from Pisa. Paris: OECD Publishing.

Ping, C., G. Schellings, and D. Beijaard. 2018. "Teacher Educators' Professional Learning: A Literature Review." Teaching and Teacher Education 75: 93-104. doi:10.1016/j.tate.2018.06.003.

Postholm, M. B. 2019. "The Teacher Educator's Role as Enacted and Experienced in School-based Development." Teachers and Teaching Theory and Practice 25 (3): 320-333. doi:10.1080/ 13540602.2019.1587403.

Pyrko, I., V. Dörfler, and C. Eden. 2017. "Thinking Together: What Makes Communities of Practice Work?" Human Relations 70 (4): 389-409. doi:10.1177/0018726716661040.

Russell, T. 2018. "A Teacher Educator's Lessons Learned from Reflective Practice." European Journal of Teacher Education 41 (1): 4-14. doi:10.1080/02619768.2017.1395852.

Russell, T., and A. Martin. 2014. "A Importância Da Voz Pedagógica E Da Aprendizagem Produtiva Nos Programas De Formação Inicial De Professores [the Importance of Pedagogical Voice and Productive Learning in Initil Teacher Education]." In Formação E Desenvolvimento Profissional De Professores: Contributos Internacionais [teacher Education and Professional Development: International Perspectives], edited by M. A. Flores, 17-40. Coimbra: Almedina.

Shagrir, L. 2019. "Intercollegiate Institution for Professional Development of Teacher Educators. Leading Changes in Teacher Education." In Leading Change in Teacher Education. Lessons from Countries and Education Leaders around the Globe, edited by T. Al Barwani, T. M. A. Flores, and D. Imig, 227-242, Milton Park: Routledge.

Smith, K. 2011. "The Multi-faceted Teacher Educator - a Norwegian Perspective." Journal of Education for Teaching 37 (3): 337-349. doi:10.1080/02607476.2011.588024.

Smith, K. 2015. "Mentoring- a Profession within a Profession." In Mentoring for Learning - Climbing the Mountain, edited by H. Tillema, G. vanWesthuisen, and K. Smith. 283-298, Rotterdam: Sense publishers.

Smith, K. 2017. "Moving beyond Rhetoric: Building a Culture to Substantiate Research Based Teacher Education." Keynote at the EARLI biennial conference. Tampere, Finland 29.0802.09.2017.

Smith, K., and M. Ulvik. 2015. "An Emerging Understanding of Mentors' Knowledge Base." In Mentoring for Learning - Climbing the Mountain, edited by H. Tillema, G. vanWesthuisen, and K. Smith.299-312, Rotterdam: Sense publishers.

Snoek, M., A. Swennen, and M. van der Klink M. 2011. "The Quality of Teacher Educators in the European Policy Debate: Actions and Measures to Improve the Professionalism of Teacher Educators." Professional Development in Education 37 (5): 651-664. doi:10.1080/ 19415257.2011.616095.

Springbett, O. 2018. "The Professional Identities of Teacher Educators in Three Further Education Colleges: An Entanglement of Discourse and Practice." Journal of Education for Teaching 44 (2): 149-161. doi:10.1080/02607476.2017.1370481.

Swennen, A., K. Jones, and M. Volman. 2010. "Teacher Educators: Their Identities, Sub-identities and Implications for Professional Development." Professional Development in Education 36 (1-2): 131-148. doi:10.1080/19415250903457893.

Tack, H., M. Valcke, I. Rots, K. Struyven, and R. Vanderlinde. 2018. "Uncovering A Hidden Professional Agenda for Teacher Educators: A Mixed Method Study on Flemish Teacher Educators and Their Professional Development." European Journal of Teacher Education 41 (1): 86-104. doi:10.1080/02619768.2017.1393514. 
Uerz, D., M. Volman, and M. Kral. 2018. "Teacher Educators' Competences in Fostering Student Teachers' Proficiency in Teaching and Learning with Technology: An Overview of Relevant Research Literature." Teaching and Teacher Education 70: 12-23. doi:10.1016/j.tate.2017.11.005.

Ulvik, M., and K. Smith. 2019. "Teaching about Teaching: Teacher Educators' and Student Teachers' Perspectives from Norway." In International Research, Policy and Practice in Teacher Education, edited by J. Murray, A. Swennen, and C. Kosnik, 123-137. Cham: Springer.

Vanassche, E., and G. Kelchtermans. 2016. "Facilitating Self-study of Teacher Education Practices: Toward a Pedagogy of Teacher Educator Professional Development." Professional Development in Education 42 (1): 100-122. doi:10.1080/19415257.2014.986813.

Vattoy, K. D., and K. Smith. 2018. "Developing a Platform for a Research-Based Teacher Education." In Norsk Og Internasjonal Lærerutdanningsforsking. Hvor Er Vi? Hvor Skal Vi Gå? Hva Skal Vi Gjøre Nå? (norwegian and International Teacher Education Research. Where are We? Where Do We Want to Go? What Shall We Do Next?), Norwegian and English K. Smith edited by, 17-44. Bergen: Fagbokforlaget.

Vieira, F. 2013. "The Scholarship of Pedagogy in Adverse Settings. Lessons from Experience." In Back to the Future: Legacies, Continuities and Changes in Educational Policy, Practice and Research, edited by M. A. Flores, A. A. Carvalho, F. I. Ferreira, and T. Vilaça, 257-276. Rotterdam/Boston/ Taipei: Sense Publishers.

Vieira, F., M. A. Flores, J. L. Silva, and J. Almeida. 2019. “Understanding and Enhancing Change in post-Bologna Pre-service Teacher Education: Lessons from Experience and Research in Portugal." In Leading Change in Teacher Education. Lessons from Countries and Education Leaders around the Globe, edited by T. Al Barwani, M. A. Flores, and D. Imig, 41-57, Milton Park, London: Routledge.

Vieira, F., J. L. C. Silva, C. C. Oliveira, F. I. Ferreira, M. A. Flores, S. Caires, and T. Sarmento. 2016. "Pressupostos E Trajetórias De Mudança - O Caso Do Núcleo De Estudos E Inovação Da Pedagogia." In La Docência Universitária: Desafios E Perspectivas, edited by P. Membiela, N. Casado, and M. I. Cebreiros, 363-367. Ourense: Educación Editora.

Wenger, E., R. McDermott, and W. M. Snyder. 2002. Cultivating Communities of Practice. Boston, MA: Harvard Business School Press.

White, S. 2019. "Teacher Educators for New Times? Redefining an Important Occupational Group." Journal of Education for Teaching 45 (2): 200-213. doi:10.1080/02607476.2018.1548174.

Yamin-Ali, J. 2018. "Tensions in the Work Context of Teacher Educators in a School of Education in Trinidad and Tobago: A Case Study." European Journal of Teacher Education 41 (1): 66-85. doi:10.1080/02619768.2017.1393516.

Zeichner, K. 2007. "Accumulating Knowledge Across Self-Studies In Teacher Education." Journal of Teacher Education 58 (1): 36-46. doi:10.1177/0022487106296219. 